\section{Primož Jurko}

University of Ljubljana, Slovenia
2021, Vol. 18 (1), 187-209(222) revije.ff.uni-lj.si/elope

https://doi.org/10.4312/elope.18.1.187-209

\title{
Semantic Prosody in Translation: Slovene and English ADV-V Combinations
}

\begin{abstract}
Semantic prosody is perhaps the most elusive meaning component established to date, and the present paper is a corpus-driven attempt to elucidate the meaning-forming process in some of the most frequent lexical items in Slovene and English. The underlying methodology is based on the novel top-down approach, which provides a semantically unmotivated point of view and is based on raw data, i.e., frequency of occurrence. The paper features a comparison of the pervasiveness of evident semantic prosody in high-frequency lexical items in Slovene and English, respectively. In closing it also deals with the problems involved in L1-L2 translation of the observed extended units of meaning, where possible translation equivalents exhibit varying levels of (mis)match in their semantic prosodies.
\end{abstract}

Keywords: semantic prosody, translation, extended unit of meaning, top-down approach

\section{Semantična prozodija in prevajanje slovenskih in angleških parov prislov-glagol}

\author{
IZVLEČEK
}

Semantična prozodija predstavlja najtežje določljivo pomensko sestavino, zato je članek osnovan na korpusni raziskavi pomenotvornih procesov pri nekaterih zelo pogostih leksikalnih enotah slovenščine in angleščine. Metodološko se članek naslanja na nov pristop z vrha navzdol, ki temelji na pogostosti sopojavljanja in tako predstavlja semantično nemotivirano alternativo ter dopolnitev dosedanjih raziskav semantične prozodije. Članek prinaša primerjavo razširjenosti izkazane semantične prozodije zelo pogostih leksikalnih enot $\mathrm{v}$ slovenščini in angleščini, predstavi pa tudi težave pri prevajanju obravnavanih razširjenih pomenskih enot iz slovenščine $\mathrm{v}$ angleščino, kjer ugotavlja različne stopnje (ne)ujemanja semantične prozodije.

Ključne besede: semantična prozodija, prevajanje, razširjena pomenska enota, pristop z vrha navzdol 


\section{Introduction}

The present paper is in many ways a logical continuation of my recent work (Jurko 2017; forthcoming) in the realm of semantic prosody. The paper features a brief survey of the development of the field and its proponents, followed by a comparison of the results of two corpus-driven studies based on the novel top-down approach to Slovene and English ADV-V pairs. One of the studies (the most frequent ADV-V pairs in Slovene) has been published before (Jurko forthcoming) and provides the empirical basis for this contrastively conceived comparison of Slovene and English extended units of meaning (presented in more detail below) with an ADV-V pair at their core. The original goal of the present study was twofold: to test the applicability of the top-down approach in a cross-linguistic setting, and to look into the translation process of extended units of meaning.

\subsection{The Rise of Semantic Prosody}

One of the main insights provided by corpus linguistics over the last 40 years is that words in isolation can no longer be regarded as the sole bearers of meaning, and this time-honoured and somewhat romantic view has been superseded by the idea that most of the time meaning is constructed through context (Rundell 2018, 1). This revelation has proved to be a gamechanger, with the paramount importance of context in the meaning-forming process in communication first been observed in the form of collocation (Sinclair 1991, 109). The new focus on exploration of recurring patterns of context and the unprecedented rise to relevance of collocation has brought about far-reaching consequences in numerous fields, notably in L2 lexicography - most prominently in EFL lexicography (Sinclair 1987) and language learning. According to his own account ${ }^{1}$ Sinclair was studying just that - a collocation - when he began to realize that there exist regularly recurring patterns beyond these, which gave rise to the extended unit of meaning. This brings us to the main topic of this paper, as an integral part of every extended unit of meaning, so Sinclair $(1998,15)$ maintains, is semantic prosody.

The notion of semantic prosody has been around for a little less than three decades. The authorship is ascribed to Louw $(1993,157)$, although it is clear that he was greatly indebted to and remains influenced by the ground-breaking ideas of Sinclair. In order to clarify what semantic prosody is, let us use Louw's wording, which remains one of the most widely used definitions of the term: "the consistent aura of meaning with which a form is imbued by its collocates". However, this rather vague description led to a number of interpretations that continue to persist today, and so semantic prosody still means many things to many linguists. In general terms it refers to favourable or (more often) unfavourable nuance of meaning that is not contained in a single item, but rather in the association of that item with others. Sinclair used the verb to set in as a case in point, and claimed that it is contaminated with nouns that are not "desirable or attractive" like rot, decay and decadence (Sinclair 1987, 155).

Whitsitt (2005) points out in his critique of the notion itself that the study of semantic prosody lacks a firm terminology. Sinclair also attempts to clear the ground and defines it as an "attitudinal or pragmatic meaning" that exists next to "the familiar classificatory

Plenary speech at the Alps-Adriatic Conference on English Language Teaching, 3 June 1994. 
meaning of the regular dictionary", i.e., denotation (Sinclair 2004, 23). Stubbs is in favour of the term discourse prosody, which he feels is better because "discourse prosodies express speaker's attitude", and are as such evaluative and reflect the speaker's reason for making the utterance (Stubbs 2001, 65). Hunston $(2007,249)$ therefore sees semantic prosody as a "contentious" term. She refers to the wedge driven between two groups of corpus linguists: one sees semantic prosody as a property of a word (i.e., as an instance of connotation), while the other looks at it as a distinguishing feature of a complex unit of meaning consisting of several co-occurring items. The former group, comprising authors such as Partington (2004), Hunston (2002) and Stewart (2010), thus believe that semantic prosody is a consequence of the spreading of the connotative colouring of a word to its collocates, which is undoubtedly a frequent phenomenon in language and makes a persuasive argument. It is not surprising then that this line of thinking has been successfully transplanted into other non-linguistic fields dealing with communication, such as social psychology (Hauser and Schwarz 2018).

The latter group do not see semantic prosody as property of a single word, its denotation or connotation, but rather as a functional or pragmatic meaning relationship, which is evidenced in all human communication (Sinclair 2004; Siepmann 2006; Hunston 2007; Philip 2011). Instead of conceiving of semantic prosody as a spin-off of the connotation of a single word, they study recurring patterns (with this word at its core, of course) and the way they function in concrete communication. Moreover, there are frequent examples where no connotation is in play, yet semantic prosody abounds, e.g., in the famous naked eye in Sinclair (2004, 30 ), which can under no circumstances be accounted for in terms of connotation. Sinclair was convinced that semantic prosody is that crucial element of real-life communication in claiming that "without it, the string of words just 'means' - it is not put to use in viable communication". In this paper Sinclair's line of thinking, with the extended unit of meaning in its focus, is adhered to and continued.

\subsection{The Extended Unit of Meaning}

An extended unit of meaning (Sinclair 2004, 30-35) consists of a core and four additional elements: collocation, colligation, semantic preference and semantic prosody. Note that collocation in terms of an extended unit of meaning differs from the usual meaning of a frequently recurring binomial. Here collocation is defined more loosely and stands for the cooccurrence of the core with another word or a string of words. Colligation is to be understood as the association of the core with a grammatical feature, such as a clause type or word class. Semantic preference refers to a range of collocators that all belong to a certain lexical field. And semantic prosody is defined as the pragmatic or functional meaning associated with the whole unit of meaning and is phrasal in nature. Philip (2009) adds a fifth element, semantic association, defined as the psychological sum of secondary meanings surrounding the entire extended unit of meaning (Philip 2009, 4). In order to keep apart the functional and affective nuances of meaning, Philip introduces the notion of semantic association, which is different from both semantic preference (as it deals with secondary meanings, i.e., psychological notions) and semantic prosody (which expresses the function of the phrase or why and how it means what it does). 
An extended unit of meaning often has some overlap in semantic association and semantic prosody. The main reason for such overlap may be the fact that semantic prosody sometimes also expresses some affective meaning, "such as reluctance or frustration or difficulty", as pointed out by Hunston $(2010,56)$.

\subsection{Previous Work on Semantic Prosody from a Bilingual Point of View}

As far as cross-linguistic comparisons are concerned, they are much fewer in number and typically involve English. Semantic prosody is an integral part of the text and should not be left out of the bilingual scope: however subtle the semantic prosody component may be, in translation the evaluative part of the source text meaning is of crucial importance. The list of contributions to the field contains comparisons of English with Chinese (Xiao and McEnery 2006; Wei and Li 2014), Portuguese (Berber Sardinha 2000; Lopes 2011), Italian (Partington 1998; Tognini-Bonelli 2001), Danish (Dam-Jensen and Zethsen 2008), Spanish (Munday 2011), French (Kübler and Volanschi 2012) and Slovene (Gabrovšek 2007; Šorli 2012, 2014; Jurko 2017).

\section{Methodology}

The fundamental trigger for the present work stems from my previous study of Slovene extended units of meaning formed around ADV-V pairs (Jurko forthcoming). That study of semantic prosody in Slovene was conceived with the ambitious goal of being as corpus-driven as possible. With this parameter set as a top priority, it was based on the novel top-down approach to semantic prosody. The next section presents a brief description of the key benefits and characteristics of this new way of tackling semantic prosody.

\subsection{The Top-down Approach: Semantic Prosody Featured in a New Light}

Semantic prosody as a concept owes its very existence to corpus linguistics. Numerous linguists have observed that semantic prosody can only be studied in large corpora, and is virtually inaccessible to intuition (e.g., Louw 1993; Hunston 2002). In recent years corpora have grown in size, reliability and representativeness, so we like to believe that contemporary corpora have avoided the limitations and traps that Biber and Finegan described thirty years ago, and that intuition and introspection have become "balanced by more empirically grounded theorizing based on the facts of usage" $(1991,220)$. However, there seem to be two important questions about semantic prosody that were never asked: how ubiquitous is it in the first place, and what is the correlation between frequency and semantic prosody - if there is any? The proposed top-down approach to semantic prosody is an attempt to provide at least partial answers to these queries. The term top-down refers to the order of descending frequency and suggests that semantic prosody should be examined systematically in the most frequent lexical items of a language. While semantic prosody has previously been studied in several lexical items that are relatively frequent (e.g., in English: happen, cause; in Slovene situacija), this is not the case with most of them (e.g., in English: budge, naked eye, set in, utterly, undergo; in Slovene: enačiti, ni videti konca, lahko primeriti). Apparently, corpus linguists are likely to notice instances or tendencies of semantic prosody while they are working on another property of a lexical item, which is unrelated to semantic prosody 
(Sinclair 2004, 30), which accounts for the relatively low overall frequency of lexical items that have been examined for semantic prosody to date. This is of course not the first time that the significance of frequency has been put into the foreground. Louw $(2000,4)$ suggests that frequency would be a good starting point for approaching semantic prosody. The proposed top-down approach also follows Kjellmer's (2005) call for a semantically unmotivated treatment of semantic prosody, which would lead to more global results.

With the objective of achieving global results the following decisions were taken:

i. The word class of verbs was selected as the general target because they have been underrepresented in comparison to other lexical word classes in studies of semantic prosody so far. This choice was based on a survey of examples in Stewart (2010), which is considered a representative and systematic presentation of work on semantic prosody up to that time: just over a fifth of all items involve a verb (18 out of 86). A quick check of the more recent body of research into the semantic prosody of verbs has shown only a handful of publications: three monolingual (Lindley 2015; Palma Gutiérrez 2019; Wang and Zou 2018), and a cross-linguistic one (Wu and Li 2016).

ii. Instead of looking for particular or 'interesting' lexical items, the list of top ten most frequent verbs in the Slovene reference corpus Gigafida $2.0^{2}$ has been made. After excluding auxiliary, linking and modal verbs the 7 th most frequent verb in Slovene has been selected for scrutiny: povedati ('tell').

iii. The selected verb has then been expanded into a lexical paradigm consisting of verbs which all share the meaning component 'to express orally'. Thus we have arrived at the list of most frequent Slovene verbs of saying, which are all ranked among the top 30 Slovene verbs in the chosen corpus; these verbs were also subjected to close observation in order to broaden the scope of this study.

iv. At that early stage in our investigation we decided to exploit the SketchEngine ${ }^{\circ}$ word-sketches of selected verbs as the more reliable option compared to intuitionbased selection of word combinations.

As noted above, this paper is based on a previous monolingual study. Therefore the methodologies applied in both studies are in general terms analogous and adhere to the same rigorous principles of selection based on frequency of occurrence. Slovene was selected as the source language, and we were interested in finding possible English translation equivalents for the Slovene units. The main reason for this is the fact that translation into non-mother tongues (also known as encoding or L1-into-L2 translation) is a necessity for all small language communities due to the lack of translators who master the source language and are native speakers of the target language (Pokorn 2009; Hirci 2012). However, L1-into-L2 translation is a difficult task, even for many skilled translators who are most of the time expected or advised (UNESCO 1976) to translate only into their mother tongue (i.e., to decode) on the basis of the so-called mother tongue principle, as advocated by, e.g., Newmark

Gigafida 2.0 reference corpus of written Slovene, available at https://www.sketchengine.eu and https://viri.cjvt.si/ gigafida. 
(1988). Needless to say, it is expected that considering the element of semantic prosody in encoding will greatly contribute to the complexity of this endeavour.

\subsection{Selection of Slovene Verbs}

The initial step of the survey was to select a broad but manageable category of lexical units that would define our search perimeter. To this end a wordlist of the most frequent verbs in Slovene was produced. Our corpus of choice was the Gigafida 2.0 reference corpus of written Slovene, accessed through the SketchEngine ${ }^{\circledast}$ portal $^{3}$, which allowed us to make use of their various tools (first and foremost Word Sketch). Gigafida 2.0 contains 1.13 billion words.

The 7th most frequent verb povedati ('tell') was chosen after excluding linking, auxiliary and modal verbs. It was established beforehand that once the best possible (in our case, the most frequent) example of Slovene verbs was selected, this would be analysed and expanded into a set of items covering the given lexical paradigm. The verb povedati has thus given us a paradigm of four additional verbs sharing the meaning component of 'express orally', which are typically used to introduce indirect or direct speech. In descending frequency order with their English rough equivalents in parentheses, these are:

- povedati ('tell'): 7 th most frequent verb in the corpus with a frequency of 728 per million,

- praviti ('say, tell', informal): 13 th most frequent verb, frequency: 540 per million,

- reči ('say'): 15th most frequent verb, frequency: 467 per million,

- dejati ('say', literary): 16th most frequent verb, frequency: 441 per million,

- govoriti ('speak, talk'): 26th most frequent verb, frequency: 337 per million.

\subsection{Selection of English Verbs}

As there is currently no reference corpus of English available on the SketchEngine portal, the EnTenTen $15^{4}$ web corpus of English was chosen to study English lexical units. It contains 13 billion words. The tenfold disparity in size between the Slovene and English corpora was not considered a hindrance, since the selected verbs belong to the most frequent lexical items in both corpora, and they also have comparable relative frequencies. The selection process was similar to that on the Slovene side: the wordlist of most frequent verbs was created and subsequently checked for verbs of saying. The verb 'say' is ranked the 6th most frequent English verb in the corpus, which is comparable to the Slovene 'povedati', which is ranked 7th. Next, the extended paradigm of English verbs with the meaning 'to express orally' was created:

- say: 6th most frequent verb, frequency: 1,434 per million,

- call: 30th most frequent verb, frequency: 446 per million,

- tell: 46th most frequent verb, frequency: 351 per million,

- speak: 86th most frequent verb, frequency: 208 per million,

- talk: 120th most frequent verb, frequency: 164 per million.

EnTenTen15 English web corpus, available at www.sketchengine.eu. 
Overall, the rankings of English verbs are lower than those of the Slovene ones, which are all ranked in the top 30. The high ranking of the Slovene of verbs of 'saying' is probably attributable to the structure of Gigafida 2.0, 64\% of which is texts from newspapers and magazines. However, as noted above their respective frequencies are apparently a closer match (with the exception of say, which is about twice as frequent as its Slovene counterpart) and fall in the approximate range of $200-500$ per million. As an additional security the rankings and frequencies of the selected five English verbs were also checked in the older LECMCI corpus, which revealed negligible differences between the corpora:

- say: 4th most frequent verb, frequency: 1,865 per million,

- call: 28 th most frequent verb, frequency: 428 per million,

- tell: 34th most frequent verb, frequency: 389 per million,

- speak: 107th most frequent verb, frequency: 175 per million,

- talk: 125th most frequent verb, frequency: 151 per million.

\subsection{Selection of Adverbs}

The next stage of the study meant we had to decide to what side of the Slovene verbs we wanted to look for phrase elements. Unlike with English verbs, which can take a modifying adverb in either preceding or following positions, in Slovene looking to the right would mean we are looking for objects of the verbs, i.e., what is being said, told or stated, and is typically expressed by nominal phrases (e.g., 'story, opinion, truth') or that-clauses. It would also mean that the role of the verb in the $\mathrm{V}+\mathrm{N}$ collocation would be that of a collocator, and the noun would be the base.

Looking to the left of the verb, on the other hand, would have these two consequences:

i. we would be looking for premodifiers of the verbs, i.e., adverbs;

ii. in the ADV-V collocation the role of the verb is that of the base and the adverb acts as the collocator.

The second option was chosen because it appears that there are currently no studies dealing with extended units of meaning with the ADV-V structure at its core. A brief examination of the more recent body of research of semantic prosody of adverbial constructions has shown only a handful of publications: three monolingual (Lindley 2015, Palma Gutiérrez 2019, Wang and Zou 2018), a cross-linguistic (Wu and Li 2016) and a diachronic one (MendezNaya 2014). However, they all significantly differ in their take on semantic prosody to the one applied in this work.

\subsection{Determination of ADV-V Pairs}

The next stage of our survey consisted of selecting the ADV-V pairs for scrutiny. The first step involved making a word sketch of each selected verb. The resulting word sketch provided us with a list of adverbs that premodify the verb in question. This step called for another

LEXMCI Corpus of English, available at https://www.sketchengine.eu. 
decision, as in most cases we were looking at a mixed bag of adverbs of time, frequency and manner that needed to be narrowed down. Adverbs of manner were chosen because time and place can be regarded as constants: whatever people 'express orally', they cannot avoid doing so at a given place at a given time, so in terms of semantic prosody the adverbs of time and place would seem to be of less interest. Whether somebody said something yesterday, today or repeatedly will undoubtedly be of less relevance compared to how they said it if we are looking for evaluative nuances of meaning in the context.

This is how we have arrived at the final list of ADV-V pairs. A random sample of 100 concordances of each pair was subsequently closely examined for semantic prosody. For each of the five chosen verbs in Slovene and English, their five most frequent adverbs of manner were studied, so a total of 5,000 concordances was manually checked.

The initial step involved determining the overall contextual semantic prosody of each concordance with the ADV-V pair as positive, negative or neutral. The following stage of research consisted of judging whether the ADV-V pair is part of an extended unit of meaning and identifying its elements as set out in section 1.3. This means that we were looking for the following five elements:

- collocation,

- colligation,

- semantic preference,

- semantic association,

- semantic prosody.

It should be noted that in the English part of the survey the element of semantic association has been omitted, as I am not a native speaker of English. Hopefully this component will be amended in a future study involving native speakers, who will be able to provide the psychological associations of the observed English extended units of meaning.

\section{Results}

The respective ADV-V pairs in Slovene and English below are presented in descending order of frequency of verbs. The Slovene empirical data be presented only in abbreviated form: numeric data tables followed by the semantic prosody of the lexical unit.

\subsection{Slovene: Adverb + povedati ('say, tell')}

The results of five most frequent adverbs of manner acting as a premodifier to povedati and their respective frequencies are presented in Table 1.

TABLE 1. Semantic prosody of adverbs of manner + povedati ('say, tell').

\begin{tabular}{|l|c|c|c|c|}
\hline Adverb & $\begin{array}{l}\text { Frequency per } \\
\text { million words }\end{array}$ & Positive \% & Neutral \% & Negative \% \\
\hline jasno ('clear/-ly') & 5.37 & 2 & 37 & 61 \\
\hline javno ('publicly') & 1.79 & 6 & 38 & 56 \\
\hline
\end{tabular}




\begin{tabular}{|l|l|l|l|l|}
\hline odkrito ('frankly') & 1.54 & 3 & 12 & 85 \\
\hline glasno ('loud/-ly') & 1.26 & 8 & 40 & 52 \\
\hline naravnost ('straight') & 0.79 & 3 & 33 & 64 \\
\hline
\end{tabular}

a. Jasno povedati ('tell clear/-ly'): the semantic prosody refers to an 'unpleasant opinion or fact shared from a position of authority'.

b. Javno povedati ('tell publicly'): the semantic prosody of 'sharing damaging or unpleasant information, often in retrospect as an excuse'.

c. Odkrito povedati ('tell frankly'): the semantic prosody of 'unpleasant information often shared out of a sense of duty or responsibility'.

d. Glasno povedati ('tell loud/-ly'): the semantic prosody refers to 'expression of suppressed opinions' or 'showing courage to express feelings'.

e. Naravnost povedati ('tell straight'): the semantic prosody is identical to that of case 3.1.1.c above (odkrito povedati), and refers to 'unpleasant information often shared out of a sense of duty or responsibility'.

\subsection{English: Adverb + say}

The results for the five most frequent adverbs of manner acting as a premodifier to say (the 6th most frequent English verb in the corpus) and their respective frequencies are presented in Table 2.

TABLE 2. Semantic prosody of adverbs of manner + 'say'.

\begin{tabular}{|l|c|c|c|c|}
\hline Adverb & $\begin{array}{c}\text { Frequency per } \\
\text { million words }\end{array}$ & Positive \% & Neutral \% & Negative \% \\
\hline simply & 1.35 & 1 & 98 & 1 \\
\hline actually & 0.86 & 4 & 95 & 1 \\
\hline really & 0.85 & 5 & 90 & 5 \\
\hline honestly & 0.77 & 56 & 28 & 16 \\
\hline clearly & 0.46 & 4 & 90 & 6 \\
\hline
\end{tabular}

The overall tendency of the studied ADV+say pairs is that they are used in neutrally nuanced contexts. The exception here is honestly, which is used to express a positive disposition of the speaker towards the topic. A random selection of five concordances with the adverb clearly is presented in Figure 1. Let us now briefly examine individual ADV-V pairs.

\begin{tabular}{|c|c|c|}
\hline appointments wouldn't work since the constitution clearly & $\underset{\text { say }}{\text { says }}$ & that while The President has to nominate, Congress has \\
\hline nmand Philemon to emancipate Onesimus; but he clearly & $\begin{array}{c}\text { says } \\
\text { say }\end{array}$ & that he won't command Philemon to do anything-insteac \\
\hline it she could travel to the hospital. Immaculee quite clearly & $\begin{array}{l}\text { said } \\
\text { say }\end{array}$ & that the group stood by her in that difficult time. This is $\mathrm{h}$, \\
\hline rrown at me. So the post title was - what the Bible clearly & $\begin{array}{c}\text { says } \\
\text { say }\end{array}$ & - because that's what I did. I picked clear examples, notI \\
\hline his attempts to save me from drowning'. The Bible clearly & $\begin{array}{c}\text { says } \\
\text { say }\end{array}$ & that God loves us and desires all people to be saved anc \\
\hline
\end{tabular}

FIgURE 1. Random concordances of 'clearly+say'. 
a. Simply say: the colligation of this pair is predominantly that of a 3rd person singular subject in mid-clausal position, frequently in religious texts. Collocation is expressed by subjects as Jesus, Paul, text, sign, Harry and by objects as word, something, hello, name, prayer. A rather vague semantic preference of religious figures and writings has been established. No semantic prosody could be determined, as the overall meaning appears to follow the denotation, i.e., say something in a simple way and avoid (over-) complicating it.

b. Actually say: in terms of colligation this pair is predominantly found in constructions with a 3rd person singular subject of a religious or political nature, often in question form (e.g., Did God actually say...?), and a pronominal object. The main collocators can be grouped as religious figures and scriptures (Bible, Jesus, God, Paul, Qur'an), a text (text, law, report, constitution) or a political figure (Obama, Bush, minister, president). The resulting semantic preference has been posited as a religious or political figure or text. Semantic prosody has been determined as 'making a counterclaim by citing a source in a position of authority'.

c. Really say: colligation and collocation in this case are almost identical to those in actually say above, which is hardly surprising due to similar denotation. The only difference is the relatively frequent use of a 1st person singular subject in negative statements, e.g., (I) can't really say... The semantic preference for a religious or political figure or text is also the same as with actually say, and the same goes for the semantic prosody of 'making a counterclaim by citing a source in a position of authority'.

d. Honestly say: this pair is the only example exhibiting a clearly positive contextual tendency with 56 positive concordances (in contrast to 28 neutral and 16 negative ones). Colligation patterns show a strong predominance of 1 st person statements preceded by the modal can and followed by a that-clause. The main collocator is the 1 st personal pronoun $I$, which is also the semantic preference of the pair. The semantic prosody has been posited as the 'expression of sincere feelings about a pleasurable experience'.

e. Clearly say: dominant colligation patterns in this case include 3rd person singular subjects that introduce quotations in the role of objects. Collocators again include religious or political figures (Jesus, God, Paul, Lord, Allah, Obama, Court) and texts (Bible, scripture, report, law, constitution). The semantic preference for a religious or political figure or text has been posited. Semantic prosody in this case has been determined as 'quoting an undisputable source of authority, often to thus win an argument'.

\subsection{Slovene: Adverb + praviti ('say, be named, be called' + informal style)}

The results for the five most frequent adverbs of manner acting as a premodifier to praviti (ranked the 13th most frequent Slovene verb) and their respective frequencies are presented in Table 3. 
TABLE 3. Semantic prosody of adverbs of manner + praviti ('be called/named').

\begin{tabular}{|l|c|c|c|c|}
\hline Adverb & $\begin{array}{c}\text { Frequency per } \\
\text { million words }\end{array}$ & Positive \% & Neutral \% & Negative \% \\
\hline $\begin{array}{l}\text { ljubkovalno } \\
\text { ('affectionately') }\end{array}$ & 0.22 & 100 & 0 & 0 \\
\hline podobno ('similarly') & 0.19 & 0 & 96 & 4 \\
\hline domače ('locally') & 0.16 & 0 & 100 & 0 \\
\hline strokovno ('technically') & 0.13 & 0 & 100 & 0 \\
\hline jasno ('clearly') & 0.13 & 0 & 22 & 78 \\
\hline
\end{tabular}

a. Ljubkovalno praviti ('be affectionately called'): the semantic prosody could not be determined.

b. Podobno praviti ('say similarly'): no semantic prosody could be established.

c. Domače ('be locally called/known'), and strokovno ('be technically called'): the semantic prosody could not be determined.

d. Jasno praviti ('clearly state'): the semantic prosody of 'speaking with the knowledge of existing laws or in reference to binding rules'.

\subsection{English: Adverb + call}

The results for the five most frequent adverbs of manner acting as a premodifier to call (ranked 30th most frequent English verb) and their respective frequencies are presented in Table 4.

TABLE 4. Semantic prosody of adverbs of manner + 'call'.

\begin{tabular}{|l|c|c|c|c|}
\hline Adverb & $\begin{array}{c}\text { Frequency per } \\
\text { million words }\end{array}$ & Positive \% & Neutral \% & Negative \% \\
\hline commonly & 0.87 & 0 & 100 & 0 \\
\hline simply & 0.73 & 0 & 100 & 0 \\
\hline usually & 0.43 & 0 & 100 & 0 \\
\hline actually & 0.31 & 4 & 92 & 4 \\
\hline affectionately & 0.28 & 100 & & \\
\hline
\end{tabular}

The overall tendency of the studied ADV+call pairs is that they are used in neutral contexts, with the exception of affectionately, which is used in positive contexts, as expected. A random selection of five concordances with the adverb affectionately is presented in Figure 2. Let us now briefly examine individual ADV-V pairs.

\footnotetext{
in the early morning to cheer for the young man I

affectionately call

-face meeting. Every other Friday is a day I like to

affectionately call

my fourth son. One mom brought champagne

damage. Shampoo-Banana, as the twin towns are

affectionately called

Demo Day. Demo day is always the same: a 3

eless beauty of a woman we very respectfully and

affectionately call

a classic American university environment,

ir almost 150 miles southeast of San Antonio. It is

affectionately called the

Grandma. See the same storm system that wr
}

FIGURE 2. Random concordances of 'affectionately + call'. 
a. Commonly call: in terms of colligation this pair predominantly appears in passive voice in dependent clauses with singular subjects. In terms of collocation the nouns family, species, plant appear. A semantic preference for scientific terms is found, as the obvious role of this unit is to provide common alternative names of such terms. No semantic prosody has been found.

b. Simply call: this unit has two denotative meanings arising from the polysemy of the verb, which calls for a separate treatment of both of them (Hoey 2005, 13).

i. The first meaning that accounts for an estimated $25 \%$ of concordances can be paraphrased as 'simply make a telephone call' and is rendered by the colligation of the vocative followed by a noun or number. Collocations are formed with the nouns office, number, department, police, center. Semantic preference for a telephone number and an institutional entity has been determined, but no semantic prosody was found.

ii. The second meaning is found in roughly $75 \%$ of concordances and can be rendered as 'simply give something another name' and its colligation patterns include frequent passive constructions preceded by adverbs often and sometimes. No semantic preference or prosody could be established.

c. Usually call: in terms of colligation this pair is predominantly used in passive constructions. No collocations were found and consequently neither semantic preference nor prosody could be established, as this ADV-V pair appears exclusively in neutral contexts.

d. Actually call: in terms of colligation this pair is predominantly used in passive constructions. No collocations were found and consequently neither semantic preference nor prosody could be established, as this ADV-V pair predominantly appears in neutral contexts.

e. Affectionately call: in terms of colligation this pair is predominantly used in passive constructions, frequently with 3rd person pronominal objects. Collocations with the pair were formed with the nouns friend, local, fan expressing an alternative endearing name of a person or inanimate entity. Neither semantic preference nor prosody could be posited.

\subsection{Slovene: Adverb + reči ('say')}

The results for the five most frequent adverbs of manner acting as a premodifier to reči (ranked the 15th most frequent Slovene verb) and their respective frequencies are presented in Table 5.

TABLE 5. Semantic prosody of adverbs of manner + reči ('say').

\begin{tabular}{|l|c|c|c|c|}
\hline Adverb & $\begin{array}{c}\text { Frequency per } \\
\text { million words }\end{array}$ & Positive \% & Neutral \% & Negative \% \\
\hline težko ('hard') & 4.59 & 0 & 91 & 9 \\
\hline mirno ('calmly/safely') & 0.82 & 14 & 79 & 7 \\
\hline tiho ('softly') & 0.72 & 0 & 95 & 5 \\
\hline preprosto ('simply') & 0.54 & 2 & 88 & 10 \\
\hline odločno ('firmly') & 0.46 & 2 & 97 & 1 \\
\hline
\end{tabular}


a. Težko reči ('hard to say'):

i. meaning 'to say with difficulty': too low in frequency $(0.1 \%$ of observed concordances) and therefore negligible.

ii. meaning 'having trouble deciding on what to say': semantic prosody of 'hesitation and weighing of options' or 'temporary indecision at the moment of speaking'.

b. Mirno reči ('calmly/safely say'):

i. meaning 'say something in a calm voice': no semantic prosody could be determined.

ii. meaning 'say something with little danger of being wrong': semantic prosody refers to 'showing confidence in what I am about to say' or 'I have evidence that shows I am right'.

c. Tiho reči ('say softly'): the semantic prosody could not be determined.

d. Preprosto reči ('simply/just say'): no collocators and hence no semantic preference could be found. Semantic association and semantic prosody could not be determined.

e. Odločno reči ('say firmly'): the semantic prosody could not be determined.

\subsection{English: Adverb + tell}

The results for the five most frequent adverbs of manner acting as a premodifier to tell (ranked 46th most frequent English verb) and their respective frequencies are presented in Table 6.

TABLE 6. Semantic prosody of adverbs of manner + 'tell'.

\begin{tabular}{|l|c|c|c|c|}
\hline Adverb & $\begin{array}{l}\text { Frequency per } \\
\text { million words }\end{array}$ & Positive \% & Neutral \% & Negative \% \\
\hline really & 0.43 & 0 & 100 & 0 \\
\hline simply & 0.37 & 3 & 90 & 7 \\
\hline repeatedly & 0.25 & 1 & 98 & 1 \\
\hline probably & 0.24 & 0 & 100 & 0 \\
\hline actually & 0.21 & 6 & 71 & 23 \\
\hline
\end{tabular}

The overall tendency of the studied ADV-V pairs is that they are used in neutral contexts, with the exception of actually, of which a quarter are used in negative contexts. A random selection of five concordances with the adverb repeatedly is presented in Figure 3. Let us now briefly examine individual ADV-V pairs.

\begin{tabular}{|c|c|c|}
\hline nal and vocational opportunities. These & repeatedly tell &  \\
\hline$y^{\prime \prime}$ ( Senator Mikulski, October 16, 2012). We were & repeatedly told & that every organization in the country needs \\
\hline l. The socioreligious communities in India who are & repeatedly told & or reminded about their social rank in society \\
\hline I and in a series of interviews early on Tuesday, he & repeatedly told & anchors such as CNN's Chris Cuomo that " $w$ \\
\hline yrammes ("Alex will be down in & told & \\
\hline
\end{tabular}

FIGURE 3. Random concordances of 'repeatedly tell'.

a. Really tell: in terms of colligation this pair is frequently preceded by the negative modal cannot. Collocators of the pair include numbers, nobody, science in the role of 
the subject, and as the object we found the nouns story, difference, truth. No semantic preference or prosody could be established.

b. Simply tell: the pair exhibits no clear colligation patterns. In terms of collocation the nouns story, people, truth frequently appear in the role of the object, while story and Jesus are found as subjects. No semantic preference or prosody could be established.

c. Repeatedly tell: colligation patterns reveal a predominance of past tense constructions, with approximately half of all concordances in the passive voice. Collocators in the role of the subject include the nouns official, officer, doctor, while the nouns public, reporter, officer, police, media are found as objects. The semantic preference for an official body or its representative has been posited, while semantic prosody has been defined as 'revelation of a wrong-doing, often expressing annoyance'.

d. Actually tell: no dominant colligation patterns have been found. Collocators include the nouns story, truth used as grammatical objects. No semantic preference or prosody was posited.

e. Probably tell: in terms of colligation the item is frequently preceded by the modals can, could, would, should and followed by the 2 nd person pronoun you. As collocators in the role of the object the nouns story, truth are found. Semantic preference and semantic prosody could not be determined.

\subsection{Slovene: Adverb + dejati ('say')}

The results for the five most frequent adverbs of manner acting as a premodifier to dejati (ranked 16th most frequent Slovene verb) and their respective frequencies are presented in Table 7.

TABLE 7. Semantic prosody of adverbs of manner + dejati ('say' + literary style).

\begin{tabular}{|l|c|c|c|c|}
\hline Adverb & $\begin{array}{c}\text { Frequency per } \\
\text { million words }\end{array}$ & Positive \% & Neutral \% & Negative \% \\
\hline odločno ('firmly') & 0.3 & 11 & 81 & 8 \\
\hline tiho ('softly') & 0.2 & 17 & 61 & 22 \\
\hline zadovoljno ('gladly') & 0.16 & 100 & 0 & 0 \\
\hline javno ('publicly') & 0.15 & 8 & 50 & 42 \\
\hline mirno ('calmly') & 0.14 & 5 & 85 & 10 \\
\hline
\end{tabular}

a. Odločno dejati ('say firmly'): no semantic prosody was determined.

b. Tiho dejati ('say softly'): no semantic prosody was determined.

c. Zadovoljno dejati ('say gladly'): no semantic prosody was determined.

d. Javno dejati ('say publicly'): no semantic prosody was determined.

e. Mirno dejati ('say calmly'): no semantic prosody was determined.

\subsection{English: Adverb + speak}

$\mathrm{ADV}+$ speak (the 86th most frequent English verb) predominantly appears in neutral contexts, as shown in Table 8. Let us now briefly examine individual ADV-V pairs. 
TABLE 8. Semantic prosodies of adverb of manner + 'speak'.

\begin{tabular}{|l|c|c|c|c|}
\hline Adverb & $\begin{array}{c}\text { Frequency per } \\
\text { million words }\end{array}$ & Positive \% & Neutral \% & Negative \% \\
\hline generally & 1.58 & 0 & 100 & 0 \\
\hline directly & 0.91 & 0 & 100 & 0 \\
\hline strictly & 0.56 & 0 & 100 & 0 \\
\hline broadly & 0.45 & 0 & 100 & 0 \\
\hline clearly & 0.41 & 19 & 72 & 9 \\
\hline
\end{tabular}

A random selection of five concordances with the adverb generally is presented in Figure 4.

$\begin{array}{lll}\text { I local community, need YOUR financial support. } & \text { Generally speaking , funding for social service programs from both } \\ \text { students, like all the others, were there on merit. } & \text { Generally speaking , we came from lower/middle class backgrounc } \\ \text { mme examples. Definition of the ranking function: } & \text { Generally speaking , the MMI ranking function was designed to inc } \\ \text { n? Yes, we do. Of course. We fail every day. But } & \text { generally speaking , the forgiveness we have experienced actually } \\ \text { cut package has had a long and tortuous history. } & \text { Generally speaking , the Democrats in the House have opposed pi }\end{array}$

FIGURE 4. Random concordances of 'generally speak'.

Below is a brief presentation of individual ADV-V pairs.

a. Generally speak and broadly speak: the two pairs are so close in their denotative meanings that it is not surprising that they have matching semantic profiles. In terms of colligation there is a clear preference for a sentence-initial position of the present participle form as a discourse organizer. No collocation candidates were found. As expected, no clear semantic preference or prosody have been determined.

b. Speak directly: a strong colligation pattern is found with the prepositions to, with followed by a pronoun or personal name. In terms of collocation the pair is relatively frequently used with the nouns God, Jesus, Lord, voice, word, Obama, Allah. Despite this, no semantic preference or prosody could be established.

c. Strictly speak: inverse in its discourse function to generally speaking above, in terms of colligation there is a strong prevalence of the present participle form (often in sentence-initial position), followed by the prepositional phrase in terms of. No collocation patterns were found, and thus no semantic preference or prosody either.

d. Clearly speak: in terms of colligation there are, as expected, strong patterns with the prepositions to, of, about. Collocators include the nouns God, Lord, Bible, Jesus, word in the role of the subject, but not in large enough instances to enable identification of the semantic preference or prosody of the unit.

\subsection{Slovene: Adverb + govoriti ('speak/talk')}

The results for the five most frequent adverbs of manner acting as a premodifier to govoriti (ranked 26th most frequent Slovene verb) and their respective frequencies are presented in Table 9. 
TABLE 9. Semantic prosody of adverbs of manner + govoriti ('speak').

\begin{tabular}{|l|c|c|c|c|}
\hline Adverb & $\begin{array}{c}\text { Frequency per } \\
\text { million words }\end{array}$ & Positive \% & Neutral \% & Negative \% \\
\hline težko ('difficult, hard') & 3.17 & 16 & 66 & 18 \\
\hline javno ('publicly') & 1.01 & 1 & 73 & 26 \\
\hline dobro ('well') & 0.77 & 3 & 97 & 0 \\
\hline tekoče ('Aluently') & 0.7 & 0 & 100 & 0 \\
\hline odkrito ('frankly') & 0.54 & 3 & 47 & 50 \\
\hline
\end{tabular}

a. Težko govoriti ('difficult to speak/talk of'): two meanings:

i. meaning 'to speak with difficulty': no semantic prosody was determined.

ii. meaning 'to find it hard to express something due to lack of information': semantic prosody of 'indecision due to lack of information; inability to predict future; opposition to an opinion expressed before'.

b. Javno govoriti ('speak publicly'): the semantic prosody refers to 'disclosure of sensitive topics'.

c. Dobro govoriti ('speak well'): no semantic prosody was determined.

d. Tekoče govoriti ('speak fluently'): no semantic prosody was established.

e. Odkrito govoriti ('speak frankly'): the semantic prosody refers to 'showing courage to discuss serious problems or innermost topics'.

\subsection{English: Adverb + talk}

The results for the five most frequent adverbs of manner acting as a premodifier to talk (ranked $120^{\text {th }}$ most frequent English verb) and their respective frequencies are presented in Table 10. A random selection of five concordances with the adverb openly is presented in Figure 5 .

TABLE 10. Semantic prosodies of adverbs of manner + 'talk'.

\begin{tabular}{|l|c|c|c|c|}
\hline Adverb & $\begin{array}{c}\text { Frequency per } \\
\text { million words }\end{array}$ & Positive \% & Neutral \% & Negative \% \\
\hline really & 0.39 & 8 & 81 & 11 \\
\hline actually & 0.28 & 13 & 82 & 5 \\
\hline openly & 0.08 & 2 & 22 & 76 \\
\hline briefly & 0.06 & 2 & 98 & 0 \\
\hline directly & 0.02 & 0 & 98 & 2 \\
\hline
\end{tabular}

imes at the same time by the same people." When people openly talk about seceding from the United States, "I consider that a f lameful tactics (2 Cor 4). Rather by living in his reality and openly talking about it as others ask us about our lives we 'set forth the tı Ieras capture high-ranking officials at Planned Parenthood openly talking about selling aborted baby cadavers/body parts for profit. I hank you so much for sharing your practical solutions and openly talking about some difficult times in your career. Please continue 1 industry executives... ZWERDLING: And people would be openly talking about the fact that their guns were being sold to criminals :

FIGURE 5. Random concordances of 'openly talk'. 
a. Really talk: in terms of colligation the pair exhibits an expected prevalence of constructions where it is followed by the prepositions about, to. As for collocation, the subject of the pair is frequently expressed by the pronoun nobody, but no semantic preference or prosody could be determined.

b. Openly talk: colligation patterns show a predominance of prepositional phrases introduced by about, of. Collocation patterning shows that as grammatical subjects the nouns leader, politician, celebrity are frequent, while the nouns issue, experience, sex, problem, feeling are found in the role of the object. The semantic preference for an intimate or burdening matter has been found, while the semantic prosody of 'sincere sharing of one's innermost topics with the aim of relief or help' has been established.

c. Talk directly: in terms of colligation the pair is followed by a prepositional phrase introduced by to, with. No firm collocations were found for the pair, so there is no semantic preference or prosody in this case.

d. Actually talk: there are no dominant colligation patterns beside the expected prepositions about, to, with following the pair. No collocation patterns, hence no semantic preference or prosody have been found.

e. Briefly talk: there are no dominant colligation patterns beside the expected prepositions about, to, with following the pair. There are no collocation patterns, so neither semantic preference nor prosody have been found.

\section{Discussion}

\subsection{Comparison of Proneness to Form Semantic Prosody}

The empirical part of the study involved the 25 most frequent Slovene and English ADV-V pairs, with the verb belonging to the lexical paradigm with the meaning 'to express orally'. There were three Slovene and one English ADV-V pairs with two meanings, although two of the Slovene items were too low in frequency to allow any observation. This means there was one polysemous pair with two meanings found in each language, so we are looking at a total of $52 \mathrm{ADV}-\mathrm{V}$ pairs with distinct meanings. In the Slovene items semantic prosody is expressed in $11 \mathrm{ADV}-\mathrm{V}$ pairs (seven negative and four neutral), while no semantic prosody is expressed in 15 ADV-V pairs, as shown in Figure 6.

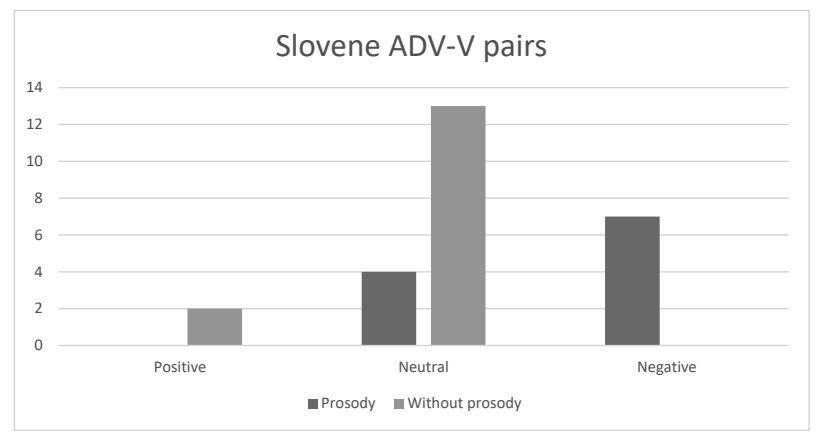

Figure 6. Slovene ADV-V pairs. 
In English there are six instances (four neutral, one negative, one positive) of expressed semantic prosody in ADV-V pairs, while no semantic prosody is expressed in $20 \mathrm{ADV}-\mathrm{V}$ pairs (19 neutral, one positive), as shown in Figure 7.

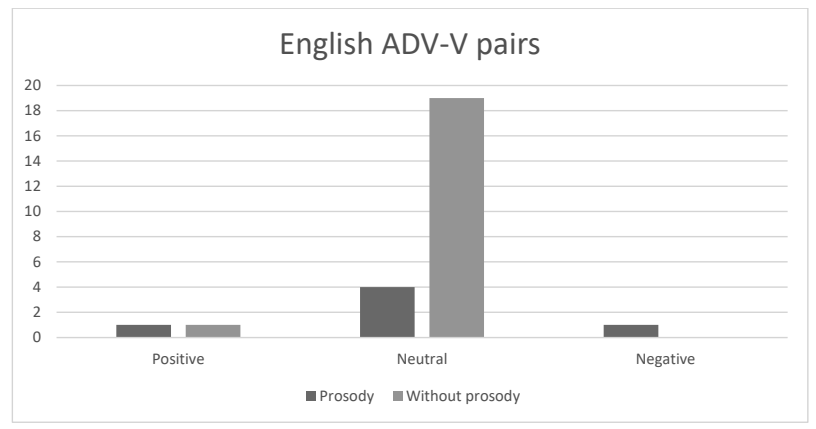

Figure 7. English ADV-V pairs.

On the whole it appears that Slovene ADV-V pairs are nearly twice as likely than their English counterparts to form extended units of meaning and develop semantic prosodies, as shown in Figure 8.

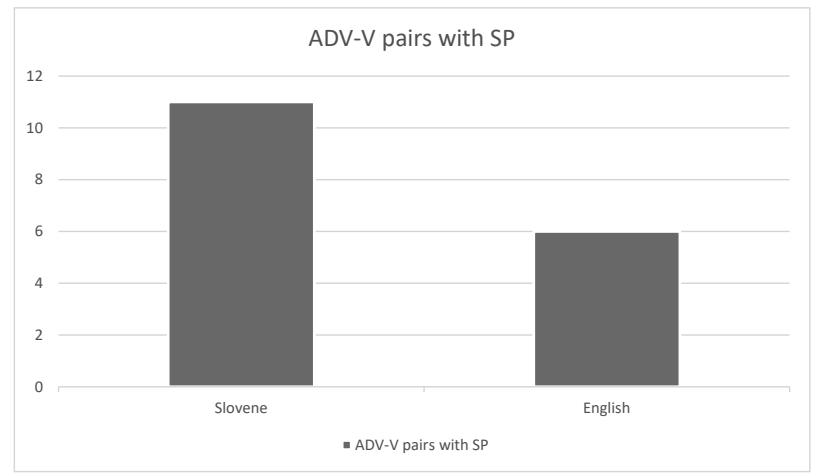

FIGURE 8. Slovene vs. English ADV-V pairs with semantic prosody.

If we look at the polarity of the discovered semantic prosodies, we can see that Slovene $\mathrm{ADV}-\mathrm{V}$ pairs support the tendency of semantic prosody to express a rather negative discourse attitude of the speaker/writer (seven out of 11 are negative). However, on the English side the situation is very different, and appears to be nicely balanced when it comes to the parameter of polarity: four out of six ADV-V pairs with expressed semantic prosody were found in neutral contexts, with one in negative and one in positive ones. Although a global uniformity across languages is not likely, future studies on a larger scale than this work will be needed to provide more evidence on this matter.

\subsection{Possible Correlation with Frequency of Occurrence?}

We next attempted to look for any properties that ADV-V pairs laden with semantic prosody had in common. In terms of their frequency of occurrence, the Slovene units with prosody 
had a notably higher relative frequency compared to the units where no semantic prosody was expressed. We have calculated the average relative frequencies of both groups, one with semantic prosody ( 1.91 per million words) and one without it ( 0.35 per million words), as shown in Figure 9.

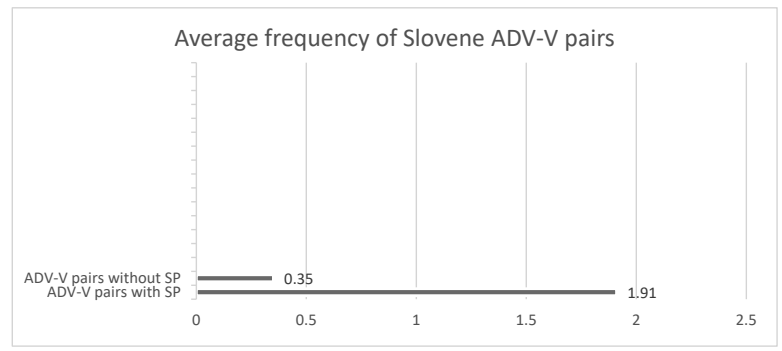

FIGURE 9. Average frequency per million words of Slovene SP units vs. units with no SP.

The same calculation was done on the English side and again the results are quite dissimilar. Here the average frequency of units with expressed semantic prosody is only marginally higher to that of units without semantic prosody, as seen in Figure 10.

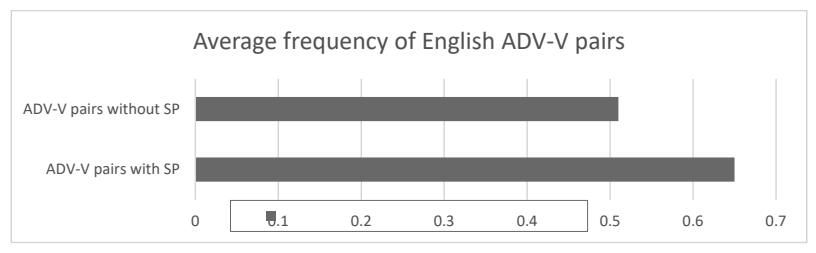

FIgURE 10. Average frequency of English ADV-V pairs.

The results for the Slovene units encouraged us to hypothesize a correlation between frequency of occurrence and the likelihood for the emergence of semantic prosody. The ratio of average frequencies Slovene units with and without semantic prosody is as high as 5 to 1 , while with the English units the ratio is much lower, at 1.27 to 1 . One of possible causes for this discrepancy might be the structure of the Gigafida 2.0 reference corpus of Slovene, which contains a very large proportion of newspaper and magazine texts. This particular feature may have pushed the frequency of Slovene verbs a notch or two higher. On the other hand, the English EnTenTen 15 corpus was compiled using a variety of web-based texts covering a broad spectrum of topics from a multitude of regional varieties of English (mostly British, but also Indian, American, New Zealand, Canadian and from the .EU web domain). Future work will therefore show whether there is indeed a connection between the frequency of occurrence and semantic prosody, and also whether the structure of the corpus is a relevant variable.

\subsection{The Search for Translation Equivalents}

As stated above, one of the aims of this work is also to look at possible translation equivalents among the analysed ADV-V pairs. We will be particularly interested to find any matches (or mismatches) in terms of semantic prosody, with Slovene as the source and English the target 
language. Here is the list of rough candidates for translation equivalence taken from our tables above:

jasno povedati - say clearly

odkrito povedati - say honestly

ljubkovalno praviti - be affectionately called

preprosto reči - simply tell/say

a. Jasno povedati - clearly say: at first sight this seems to be a good match, but when we look at the numbers, it starts to look off: the Slovene unit is more than 10-times more frequent than the English one. However, the main discrepancy between them is due to their different semantic prosodies: jasno povedati has in most cases the semantic prosody of an 'unpleasant opinion or fact shared from a position of authority', while in clearly say this is not expressed. There are, to be sure, many contexts where clearly say is an acceptable translation, however if we take a look at the concordance below, it simply will not do.

a lahko vrnila na svoje tamkajšnje položaje. Vendar so Američani jasno povedali , kdo lahko vkoraka v mejno območje. Tja niso pustili e

FiguRE 11. Concordance of jasno povedati with clearly expressed semantic prosody.

A possible alternative translation with the appropriate semantic prosody might be to make something perfectly clear, and the next expanded concordance is a good example.

their ports and bases to the American military. $<p><p>$ The myth of "national security," is being foisted on the nations of the Pacific and Southeast Asia to instill fear that China and Russia have evil intentions to dominate the region. The U.S. military has made it perfectly clear their intentions are to encircle China and Russia, to impeded their growth by controlling access to the world's resources, and to dominate the earth through a so-called Pax Americana. In other words, full-spectrum dominance

FIGURE 12. Concordance of 'make something perfectly clear' with a matching semantic prosody.

b. Odkrito povedati - honestly say: although the adverbs are not a clear denotative match, this is certainly a viable candidate. While the frequencies are not so far apart, either, the problem lies again in their respective semantic prosodies: negative for the Slovene unit ('unpleasant information often shared out of a sense of duty or responsibility'), positive for the English ('expression of sincere feelings about a pleasurable experience'). I do not believe there exists a passable translation of the next concordance with honestly say.

zanj primerni ustvarjalni seti, preprosti pripomočki za ročna dela, zahtevnejše družabne igre in ne nazadnje tudi računalnik. "Pri vaših letih vam brez vsake preiskave odkrito povem, da se boste morali navaditi živeti z bolečino. Spreminjala vas bo iz dneva v dan. Včasih jo boste komaj čutili, a se bo iznenada spet pojavila, dokler vas lepega dne ne bo skoraj ohromila pri povsem

FiguRE 13. Concordance of 'odkrito povedati'.

In this case a paraphrase with the adjective/adverb blunt $(-l y)$ is probably a better solution.

c. Ljubkovalno praviti - be affectionately called: life can also be good sometimes, and here we have a full match. The frequencies of both items are practically identical, and so is the semantic prosody. Although this is not exactly a formidable challenge 
for a well-versed translator, not all university students of translation would find this a straightforward equivalent.

d. Preprosto reči - simply say/tell: in this case the choice of the verb in the English translation equivalent will depend on the context (as always, one might add). What is more, semantic prosody will not stand in the way as it is not expressed in either the source or the target unit.

\section{Conclusion}

The original goal of the present study was twofold: to test the applicability of the top-down approach in a cross-linguistic study, and to look into the translation process of extended units of meaning. The top-down approach has proved to be a practical alternative to semantically based methodological concepts, although it is probably best seen as a valuable complementary tool that can hopefully contribute to the rapidly developing sphere of corpus linguistics.

In terms of translation of extended units of meaning there are several layers of interconnected problems and this study has barely scratched the surface. Clearly, there are limitations in terms of scope and corpora structure, which should be addressed in future work. It is my firm belief that students of translation should be made aware of the existence of semantic prosody. In particular they are sure to benefit from coming to grips with the meaning-forming process involved in the translation of highly complex lexical items that are so often taken at face value.

\section{References}

Berber Sardinha, Tony. 2000. "Semantic Prosodies in English and Portuguese." Cuadernos de Filogía Inglesa 9 (1): 93-110. http://www2.lael.pucsp.br/-tony/temp/publications/2000murcia_prosodies.pdf.

Biber, Douglas, and Edward Finegan. 1991. "On Exploitation of Computerized Corpora in Variation Studies." In English Corpus Linguistics. Studies in Honour of Jan Svartvik, edited by Karin Aijmer, and Bengt Altenberg, 204-20. London: Routledge.

Dam-Jensen, Helle, and Karin Korning Zethsen. 2008. "Translator Awareness of Semantic Prosodies." Target: International Journal on Translation Studies 20 (2): 203-21. https://doi.org/10.1075/ target.20.2.02dam.

Gabrovšek, Dušan. 2007. "Connotation, Semantic Prosody, Syntagmatic Associative Meaning: Three Levels of Meaning?” ELOPE 4 (1-2): 10-28. https://doi.org/10.4312/elope.4.1-2.9-28.

Hauser, David, and Norbert Schwarz. 2018. "How Seemingly Innocuous Words Can Bias Judgment: Semantic Prosody and Impression Formation.” Journal of Experimental Social Psychology 75: 11-18. https://doi.org/10.1016/j.jesp.2017.10.012.

Hirci, Nataša. 2012. "Electronic Reference Resources for Translators: Implications for Productivity and Translation Quality." The Interpreter and Translator Trainer 6 (2): 219-35. https://doi.org/10.1080/13 556509.2012.10798837.

Hoey, Michael. 2005. Lexical Priming. London: Routledge.

Hunston, Susan. 2002. Corpora in Applied Linguistics. Cambridge Applied Linguistics Series (CALS). Cambridge: Cambridge University Press.

—. 2007. "Semantic Prosody Revisited." International Journal of Corpus Linguistics 12: 249-68. https://doi. org/10.1075/ijcl.12.2.09hun.

-. 2010. Corpus Approaches to Evaluation. London: Routledge.

Jurko, Primož. 2017. "Pragmatic Meaning in Contrast: Semantic Prosodies of Slovene and English." Perspectives 25 (1): 157-76. https://doi.org/10.1080/0907676X.2016.1165262. 
—. forthcoming. "Semantic Prosody of Slovene Adverb-Verb Collocations: Introducing the Top-Down Approach." CORPORA.

Kjellmer, Göran. 2005. "Collocations and Semantic Prosody: Abstract." AAACL 6/ ICAME Conference, 12 - 15 May, 2005, Ann Arbor. http://robfelty.com/design/archives/corpusconference/abstracts/ abstract48.pdf.

Kübler, Natalie, and Alexandra Volanschi. 2012. "Semantic Prosody and Specialised Translation, or How a Lexico-Grammatical Theory of Language Can Help with Specialised Translation.” In Corpus Informed Research and Learning in ESP: Issues and Applications, edited by Alex Boulton, Shirley Carter-Thomas, and Elizabeth Rowley-Jolivet, 103-34. Studies in Corpus Linguistics. Amsterdam: John Benjamins.

Lindley, Jori. 2015. "A Corpus-Based Cognitive-Functional Study of the Meaning and Use of 'Always' and 'Never', and Related Phenomena, in American English." PhD diss., University of California. http:// www.escholarship.org/uc/item/36n1j6gp.

Lopes, Maria Cecilia. 2011. "Tradução, padrões e nuances: um estudo de Linguística de Corpus sobre diferentes prosódias semânticas na língua fonte e na língua alvo." Revista Brasileira de Linguística Aplicada 11: 747-72. https://doi.org/10.1590/S1984-63982011000300008.

Louw, Bill. 1993. "Irony in the Text or Insincerity in the Writer? The Diagnostic Potential of Semantic Prosodies." In Text and Technology: In Honour of John Sinclair, edited by Mona Baker, Gill Francis, and Elena Tognini-Bonelli, 157-76. Philadelphia: Benjamins.

—. 2000. "Contextual Prosodic Theory: Bringing Semantic Prosodies to Life." In Words in Context: A Tribute to John Sinclair on His Retirement, edited by Chris Heffer and Helen Sauntson, 48-94. Birmingham: University of Birmingham. http://www.revue-texto.net/docannexe/file/124/louw_ prosodie.pdf.

Méndez-Naya, Belén. 2014. "Out of the Spatial Domain 'Out'-Intensifiers in the History of English.” Folia Linguistica Historica 35 (1): 241-74. https://doi.org/10.1515/flih.2014.007.

Munday, Jeremy. 2011. "Looming Large: A Cross-Linguistic Analysis of Semantic Prosodies in Comparable Reference Corpora." In Corpus-Based Translation Studies: Research and Applications, edited by Alet Kruger, Kim Wallmach, and Jeremy Munday, 169-86. London: Continuum.

Newmark, Peter. 1988. A Textbook of Translation. London: Prentice Hall.

Palma Gutiérrez, Macarena. 2019. "Semantic Prosody in Middle Construction Predicates: Exploring Adverb + Verb Collocation in Middles." In Computational and Corpus-Based Phraseology, edited by Gloria Corpas Pastor and Ruslan Mitkov, 11755. Cham: Springer.

Partington, Alan. 1998. Patterns and Meanings: Using Corpora for English Language Research and Teaching. Amsterdam: John Benjamins.

—. 2004. "Utterly Content in Each Other's Company: Semantic Prosody and Semantic Preference." International Journal of Corpus Linguistics 9 (1): 131-56. https://doi.org/10.1075/ijcl.9.1.07par.

Philip, Gill. 2009. "Why Prosodies Aren't Always Present: Insights into the Idiom Principle." In CL2009 Corpus Linguistics Conference, edited by Michaela Mahlberg, Victorina González-Díaz, and Catherine Smith. Liverpool: University of Liverpool. http://ucrel.lancs.ac.uk/publications/cl2009/.

- 2011. Colouring Meaning. Collocation and Connotation in Figurative Language. Amsterdam: John Benjamins.

Pokorn, Nike Kocijančič. 2009. "Natives or Non-natives? That Is the Question...: Teachers of Translation into Language B.” The Interpreter and Translator Trainer 3 (2): 189-208.

Rundell, Michael. 2018. "Searching for Extended Units of Meaning - And What to Do When You Find Them." Lexicography Journal of Asialex 5: 5-21. https://doi.org/10.1007/s40607-018-0042-1.

Siepmann, Dirk. 2006. "Collocation, Colligation and Encoding Dictionaries. Part II: Lexicographical Aspects." International Journal of Lexicography 19 (1): 1-39.

Sinclair, John McHardy. 1987. Collins COBUILD Advanced Learner's Dictionary. London: Collins ELT.

—. 1991. Corpus, Concordance, Collocation. Oxford: Oxford University Press.

—. 1998. “The Lexical Item.” In Contrastive Lexical Semantics, edited by Edda Weigand, 1-24.

Amsterdam: Benjamins.

-. 2004. Trust the Text: Language, Corpus and Discourse, edited with Ronald Carter. London: Routledge.

Stewart, Dominic. 2010. Semantic Prosody: A Critical Evaluation. New York: Routledge. 
Stubbs, Michael. 2001. Words and Phrases: Corpus Studies of Lexical Semantics. Oxford: Blackwell.

Šorli, Mojca. 2012. "Semantična prozodija v teoriji in praksi - korpusni pristop k proučevanju pragmatičnega pomena: primer slovenščine in angleščine.” In Dvojezična korpusna leksikografija: slovenšcina v kontrastu: novi izzivi, novi obeti, edited by Mojca Šorli, 90-116. Ljubljana: Trojina, zavod za uporabno slovenistiko.

—. 2014. "Pragmatični pomen v dvojezičnem slovaropisju." PhD diss., University of Ljubljana, Faculty of Arts.

Tognini-Bonelli, Elena. 2001. Corpus Linguistics at Work. Amsterdam: John Benjamins.

UNESCO. 1976. "Recommendation on the Legal Protection of Translators and Translations and the Practical Means to improve the Status of Translators." http://portal.unesco.org/en/ev.php-URL_

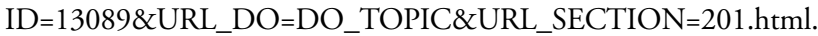

Wang, Huijuan, and Yufeng Zou. 2018. "The Semantic Features of 'v+adv' in Native English Public Speaking." Theory \& Practice in Language Studies 8 (12): 1636-48. https://doi.org/10.17507/ tpls.0812.09.

Wei, Naixing, and Xiaohong Li. 2014. "Exploring Semantic Preference and Semantic Prosody across English and Chinese: Their Roles for Cross-Linguistic Equivalence." Corpus Linguistics \& Linguistic Theory 10 (1): 103-38. https://doi.org/10.1515/cllt-2013-0018.

Whitsitt, Sam. 2005. "A Critique of the Concept of Semantic Prosody." International Journal of Corpus Linguistics 10: 283-305. https://doi.org/10.1075/ijcl.10.3.01whi.

Wu, Zhong, and Lihua Li. 2016. "A Contrastive Study on Semantic Prosodies of Minimal Degree Adverbs in Chinese and English." In Semantic Technology - 5th Joint International Conference, JIST 2015, Yichang, China, November 11-13, 2015, Revised Selected Papers, edited by Guilin Qi, Kouji Kozaki, Jeff Z. Pan, and Siwei Yu, 209-15. Springer.

Xiao, Richard, and Tony McEnery. 2006. "Collocation, Semantic Prosody and Near Synonymy: A CrossLinguistic Perspective.” Applied Linguistics 27 (1): 103-29. https://doi.org/10.1093/applin/ami045. 